Article

\title{
Youth Unemployment and Mental Health: The Mediating Role of Embodiment
}

\author{
Kelly Huegaerts ${ }^{1, *(1)}$, Bram Spruyt ${ }^{2}$ (D) and Christophe Vanroelen ${ }^{1,3}$ \\ 1 Interface Demography, Vrije Universiteit Brussel, 1050 Brussels, Belgium; cvroelen@vub.be \\ 2 Research Group TOR, Vrije Universiteit Brussel, 1050 Brussels, Belgium; Bram.Spruyt@vub.be \\ 3 Health Inequalities Research Group (GREDS), Universitat Pompeu Fabra, 08005 Barcelona, Spain \\ * Correspondence: kelly.huegaerts@vub.be; Tel.: +32-2-614-8138
}

Received: 15 May 2018; Accepted: 13 June 2018; Published: 20 June 2018

\begin{abstract}
Background: This study investigates the association between forms of capital and mental health among unemployed youth, with a specific focus on the mediating role of feelings of deprivation and self-esteem as "mechanisms of embodiment". Methods: The study is based on a primary data collection among unemployed Brussels youth in the transition from education to employment (2015; 18- to 29-year-olds; $N=1151$ ). Multi-group Structural Equation Modeling (SEM) is used to explore the association between forms of capital, mechanisms of embodiment and mental health. Results: Our results show that different forms of capital are related to the mental health of unemployed youth. These associations are partly mediated by feelings of deprivation and self-esteem. Clear gender differences in these relations are found. Conclusions: The results of this study contribute to the body of knowledge regarding the mental health situation during the transition from education to employment, by showing how "subjective mechanisms" are explaining the relations between "objective resources" and mental health.
\end{abstract}

Keywords: youth unemployment; transitions in youth; mental health; forms of capital; embodiment

\section{Introduction}

The transition from adolescence to adulthood is characterized by several major life changes: leaving the parental house; starting a (stable) partner relationship; finding (stable) employment; etc. [1,2]. The impact of these transitions on one's life can vary in terms of their magnitude, controllability and predictability [2]. Regarding employment, many European countries currently face high structural youth unemployment rates [3,4]. In Belgium, the Brussels Capital Region is no exception to this [5,6]. Moreover, we know from previous research on the transition from adolescence to adulthood of Brussels' unemployed youth that there is a harmful relationship between unemployment and mental health [7]. Additionally, this relationship is likely to be different for men and women [8-10]. We also know that within the group of unemployed youth, several personal resources-e.g., financial deprivation, low educational attainment or low self-esteem-affect this relationship [11,12]. Consequently, health inequalities not only emerge between employed and unemployed youth, but also among unemployed youth. Little, however, is known about the underlying "mechanisms of embodiment" explaining the relationship between personal resources and mental health in unemployment for young people. Therefore, the aim of this study is to gain more insight into these mechanisms of embodiment. More specifically, our study will investigate how personal resources are associated with mental health of unemployed Brussels' youth through mechanisms of embodiment. To do so, we use data from 1.151 young unemployed living in the Brussels Capital Region. 


\subsection{Personal Resources and Mental Health}

Personal resources can be conceptualised with reference to Bourdieu's theory on forms of capital [13]. Bourdieu argues that economic capital (translated into money), social capital (the resources a person can effectively mobilize through his/her network) and institutionalized cultural capital (education, knowledge and skills that are achieved and/or ascribed) are three different forms of exchange that people can appeal to in safeguarding their life chances [13]. From previous research, we know that these forms of capital affect the transition of youth towards employment [14], and that the availability, or absence, of these forms of capital affects young adults' social identities, confidence, competence, character, values and aspirations [12].

In the past, several studies also found relations between these forms of capital and the mental health of unemployed youth. For instance, a negative relationship was found between the mental health of unemployed youth and poverty of the parental household [15-17]. Parental educational level influences adult well-being [18] and differences in mental and general subjective health were found to be related to the own educational attainment of unemployed youth [19-23]. Also, the absence of social and family support negatively affects the health of individuals during the transitional phase into adulthood [12,24,25]. Moreover, Crowe, Butterworth and Leach [16] found that the relationship between adverse mental health and low social support is stronger among men compared to women.

Thereupon, we assume that "a lack of (sufficient) capital" is associated with mental health problems among unemployed youth. Proxies used for different forms of capital—seen as an indication of one's more or less stable personal resources-are one's financial situation, social support and parental as well as own educational attainment.

\subsection{Embodiment}

This study is particularly interested in how these different forms of capital are internalised. That is, we are interested in the explanatory pathways linking forms of capital to mental health among the unemployed (youth). In order to understand the process of internalization, Krieger's [26,27] concept of embodiment is particularly clarifying. It presumes that the distribution of health, disease and well-being of individuals is not only related to the embodiment of biological history, but also to the embodiment of social history throughout time [26-28]. Because people have access to different forms of capital, people will differ in the ways in which they embody the world they are living in, resulting in inequalities in health.

When investigating "the embodiment" of forms of capital upon the mental health of unemployed youth, two possible mechanisms can be hypothesised. A first mechanism is based on the notion that youth will adapt their professional expectations based on their embodiment of available forms of capital and interpret their deprived situation as a personal failure. Current Western societies combine persistent social inequalities with a cultural context that urges individuals to interpret one's experiences and social position(s) through an 'individualised lens'. An extensive body of literature has documented how institutional practices and public discourse favour interpretations that put heavy emphasis on individual achievement and personal accountability [29,30]. Scholars have always warned that such a cultural context offers those at the bottom of the social ladder little resources to lead a satisfactory subjective existence [31]. A logical outcome of this reasoning is the expectation that people will accept their situation and adjust their expectations accordingly. As a consequence of this perspective, a lack of social, cultural and economic resources may result in adolescents' perception that their future capabilities are limited [21,22,32] and the conviction that it is impossible to "succeed", no matter what, because of personal socio-economic and demographic characteristics. Such feelings of deprivation [33] can leave an enduring mark on an adolescent growing up in a situation of economic and cultural deprivation [32]. Parental support may attenuate the development of feelings of deprivation [34]. Moreover, the presence of a sense of deprivation tends to increase with decreasing parental socio-economic status [34,35]. The notion of passivity that can come forth from this idea of "why try?" is also associated with mental health problems [36]. In this paper, 
we will test the first hypothesis that feelings of deprivation, which are triggered by the embodiment of forms of capital, have a direct negative relationship with mental health outcomes.

A second mechanism starts from the opposite position and considers feelings of deprivation not as a form of negative adjustment, but as a way to improve self-esteem during a period of distress, as is the case with unintended unemployment [37,38]. Hogg's uncertainty-reduction theory is based on the premise that feeling uncertain about oneself-that is, who we are, how we relate to others and where we are socially located-is uncomfortable and powerfully motivating. When confronted with uncertainty, people strive to reduce uncertainties. This process is not a personal matter but is performed through socially constructed strategies that circulate in the form of stories. Often these stories are based on a vague group identification (e.g., "people like us"). By explaining one's personal situation as the result of a group opposition (e.g., "people like us never get a fair chance"), one reduces the share of personal responsibility in the experienced vulnerability. Seen from this perspective, feelings of deprivation may not be the internalization of personal failure but rather an attempt to safeguard one's personal self-esteem while finding oneself in a socially deprived situation. The existence of a direct relationship between forms of capital and self-esteem has already been demonstrated. High social support is related to elevated levels of self-esteem [25], especially among women compared to men [39]. While lower parental socio-economic status is related to lower self-esteem among youth in the transition to adulthood [40,41]. This relationship is found to be stronger among men compared to women [39]. With regard to youth's own educational attainment, research demonstrates that the lower educated tend to have lower self-esteem [42]. Based on the insights from uncertainty-reduction theory, a contrasting second hypothesis assumes that: feelings of deprivation are not negatively related to mental health outcomes directly. Nonetheless, it can be assumed that only when feelings of deprivation negatively affect one's self-esteem, an indirect relationship with adverse mental health can be expected. In other words, self-esteem acts as a buffer in the relationship between deprivation (affected by forms of capital) and adverse mental health amongst unemployed youth.

In sum, this paper aims to explore how forms of capital are associated with mental health in a sample of unemployed Brussels' youth who are entering the labour market. More specifically, this study wants to investigate whether and how processes of embodiment affect the relationship between forms of capital and mental health and if they differ between men and women.

\section{Methods}

\subsection{Context of Our Study}

This study focusses particularly on the Brussels Capital Region because, even though this Belgian region is an important supplier of employment, it is also the region with the highest youth unemployment rates out of the three Belgian regions [43]. During the second quarter of 2016, 36.4\% of Brussels youth were unemployed compared to $14.3 \%$ in Flanders and $29.3 \%$ in Wallonia [44]. These high youth unemployment rates are in part explained by the educational mismatch. Namely, a large share of the Brussels youth is lower educated [45], while most employment in Brussels is oriented towards skilled non-manual workers. As a consequence, many young people living in Brussels are excluded from these employment opportunities.

\subsection{Data}

To answer the research questions, information from a primary data collection conducted between August and December 2015 was used. A self-administered questionnaire was distributed at the information sessions for Brussels youth (18- to 29-year-olds) registering themselves as unemployed. All participants were entering the labour market for the first time. These informative sessions were organised by Actiris, the public employment service of the Brussels Capital Region. This informative session was a first step for all first-time enrolling youth in order to open their right to claim unemployment benefits, which means that this recruitment channel provided a relatively unbiased 
access to the targeted population. There were no indications of strong sampling biases in our sample. However, it should be noted that within this age group, not all youth were enrolled at the public employment service. More specifically, students, employed youth, NEET-youth (Not in Education, Employment or Training) and youth who were seeking employment without calling upon the benefit or labour counselling system were not included in the sample. In total, 36.77\% of all eligible respondents-during the time frame of our data collection-participated in the study $(N=1151)$. Due to missing data, our final analyses were based on 1136 respondents. Our sample consists of $45.6 \%$ men and 54.4\% women and the average age was 22 years old. Ethical approval for our study was received from the Vrije Universiteit Brussel Medical ethics board (2015/229; B.U.N.143201525066). Participants were fully informed about the study by a researcher and each respondent signed an informed consent form prior to participation.

\subsubsection{Dependent Variables}

Mental health was measured using the 12-item General Health Questionnaire (GHQ12) developed by Goldberg and Williams [46] (Cronbach's alpha $=0.848$ ) and can be considered as a good indicator for mental health outcomes. The 12 items with a four-point Likert-scale were recoded as follows: response values 1-2 and 3-4 of each item were recoded into respectively ' 0 ' and ' 1 '. By doing so, we reduced potential bias from respondents who consistently select middle response items [47]. Mental health was included as a latent construct; higher values indicate poorer mental health.

\subsubsection{Independent Variables}

Forms of capital. Institutionalized cultural capital was operationalized by means of parental educational attainment and the educational attainment of the respondent. Parental educational attainment was measured using two items: "My father/mother has ... ", with response categories (1) Maximum secondary education; (2) Post-secondary education. Both variables were recoded into a single item combining the educational attainment of both parents: (1) Both parents are low-educated; (2) One parent is low-educated and one parent is high-educated; (3) Both parents are high-educated. The educational level of the individual was based on a single item with the following answering categories: (1) Maximum secondary and (2) Post-secondary education. For economic capital, a single variable was used as a proxy, namely "How would you describe the financial situation of your family?". Answers were (1) Very rich; (2) Rich; (3) Comfortable; (4) Modest; and (5) Poor. Due to low sample sizes in response categories 1 and 5, the variable was recoded to distinguish between (1) Poor; (2) Modest; and (3) Comfortable. The distribution of these variables is shown in Table 1.

Table 1. Frequency of the different categories of economic and cultural capital for men and women-N (\%).

\begin{tabular}{lcc}
\hline & Men & Women \\
\hline Economic capital & & \\
\hline Poor & $37(7.4 \%)$ & $45(7.6 \%)$ \\
$\quad$ Modest & $240(48.1 \%)$ & $291(48.9 \%)$ \\
$\quad$ Comfortable & $222(44.5 \%)$ & $259(43.5 \%)$ \\
\hline Cultural capital & & \\
\hline Educational level of the parents & & \\
$\quad$ Both parents are low-educated & $216(51.2 \%)$ & $261(51.5 \%)$ \\
$\quad \begin{array}{l}\text { One parent is low-educated and one parent is high-educated } \\
\text { Both parents are high-educated }\end{array}$ & $87(20.6 \%)$ & $95(18.7 \%)$ \\
\hline Educational level of the respondent & $119(28.2 \%)$ & $151(29.8 \%)$ \\
$\quad$ Maximum secondary & $341(67.3 \%)$ & $328(54.3 \%)$ \\
Post-secondary education & $166(32.7 \%)$ & $276(45.7 \%)$ \\
\hline
\end{tabular}


The latent variable for social capital was based on a set of questions about social support, using the Duke-UNC Functional Social Support Questionnaire [48]. This 8-item questionnaire (Cronbach's alpha $=0.898$ ) used a 5-point Likert scale, including: (1) Much less than I would like; (2) Less than I would like; (3) Some but I would like more; (4) Almost as much as I would like; and (5) As much as I would like". Included were questions such as "I get useful advice about important things in life" and "I have people who care about what happens to me". Higher scores indicated higher perceived social support.

Feelings of deprivation was conceptualised as a latent construct using a scale developed by Pelleriaux [33]. For this research, we selected 5 items referring to (un)employment. These items referred to the notion of being part of a "group of people like them" (Cronbach's alpha $=0.863)$ and were scored on a 5-point Likert scale: (1) Strongly disagree; (2) Disagree; (3) Undecided; (4) Agree and (5) Strongly agree. Included were questions such as "My future is set: unemployment, little money and little hope." and "A good career, that is not for us.". In the analyses, higher scores presented a higher presence of feelings of deprivation.

The latent construct "self-esteem" was measured using a 10-item scale of Rosenberg [49] (Cronbach's alpha $=0.798$ ) and included questions such as "On the whole, I am satisfied with myself" and "I feel that I'm a person of worth, at least on an equal plane with others". Response categories for the five positively asked questions were (1) Strongly disagree; (2) Disagree; (3) Agree; and (4) Strongly agree. The response categories of the five negatively asked questions were coded inversely, so that a higher score always indicated higher self-esteem.

\subsubsection{Control and Stratification Variables}

Age was included in the model as a numeric control variable ranging between 18 and 29 years old. Gender was used as a stratification variable in our model.

\subsection{Methodology}

Firstly, a confirmatory factory analysis was applied to the four measurement models of the latent constructs social support; self-esteem; feelings of deprivation; and mental health. The goodness-of-fit was evaluated using the Chi-Square goodness-of-fit test $\left(\chi^{2}(d f)\right)$; Root Mean Squared Error of Approximation (RMSEA); Comparative Fit Index (CFI); Tucker-Lewis Index (TLI). The RMSEA was considered acceptable if values were less than 0.07 [50]. For both the CFI and TLI, values greater than 0.09 were deemed acceptable [51]. We allowed error covariances between several questions of our latent construct because consecutive questions, questions with similar wording or content can be a source of additional indicator covariation [52,53].

Secondly, we combined the different measurement models to test a theory-based multi-group structural equation model (Figure 1) using STATA 14. Because of non-normality of the data, we used the robust maximum likelihood estimator in our analysis. The tested models were evaluated by investigating modification indices and a test for invariance of parameters across groups. Furthermore, goodness-of-fit of the structural equation models was evaluated using the Chi-Square goodness-of-fit test $\left(\chi^{2}(d f)\right)$; Root Mean Squared Error of Approximation (RMSEA); Comparative Fit Index (CFI); Tucker-Lewis Index (TLI). Direct $\left(c^{\prime}\right)$, indirect $(a . b)$ and total $(c)$ effects were calculated, with $c=c^{\prime}+(a . b)$ [54]. 


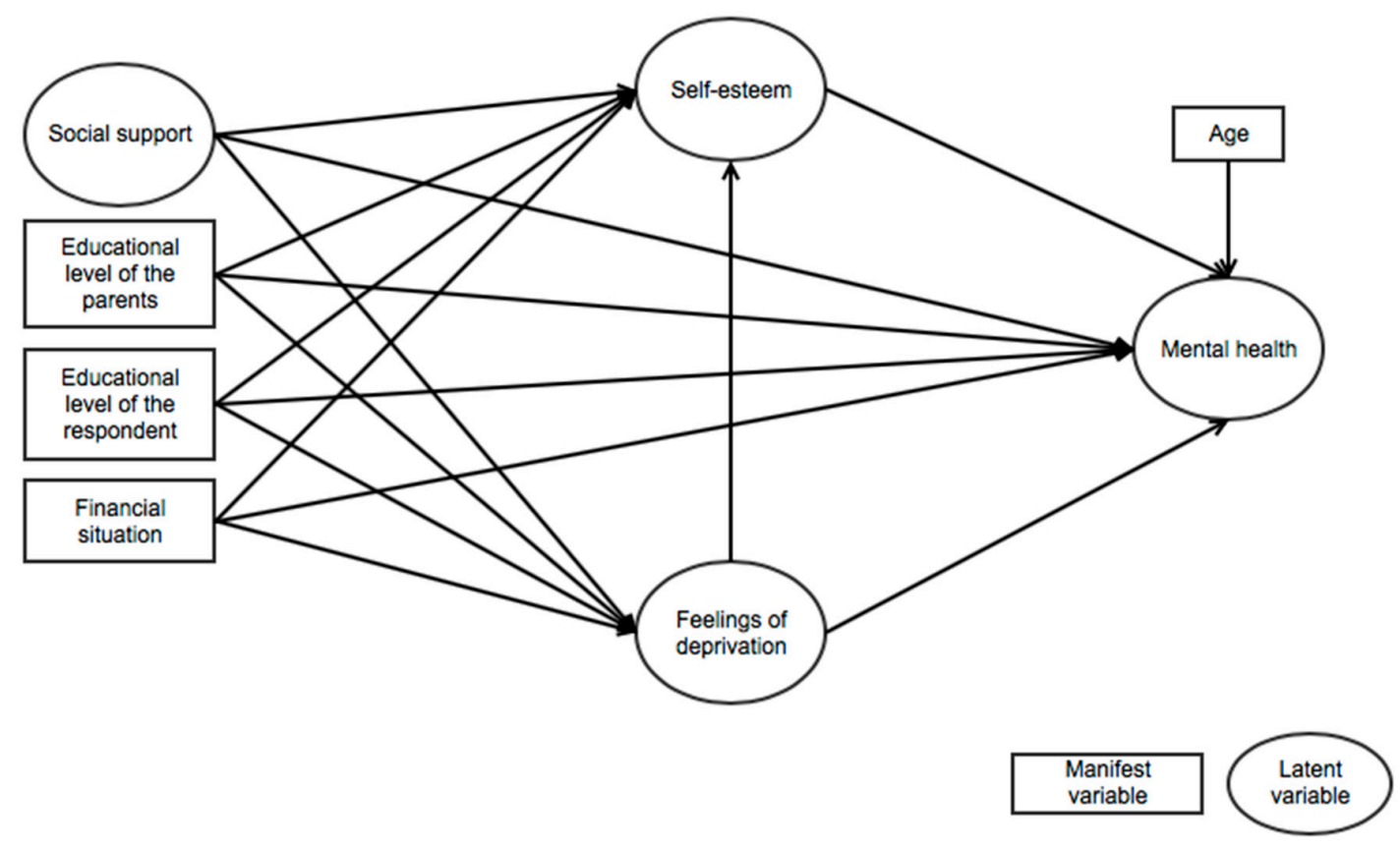

Figure 1. Final Structural Equation Model.

\section{Results}

Table 2 shows that all correlations between the four latent constructs are significant, for both men and women, meaning that high feelings of deprivation, low self-esteem, low social support and poor mental health are strongly related to one another. Furthermore, high social support among women is significantly correlated with increasing age, a better financial situation and higher individual and parental educational levels. For men, high social support is clearly correlated with their own and their parents' educational level. For both men and women, high feelings of deprivation are significantly correlated with a poorer self-perceived financial situation and with low individual and parental educational levels. The correlations also show that, among men, high self-esteem is clearly correlated with increased educational attainment. Among women, high self-esteem is correlated with a good financial situation. Moreover, poor mental health is correlated significantly with a poor self-perceived financial situation among women and a higher educational level of the parents among men. Furthermore-for both men and women-higher parental and individual educational attainment and increasing age are significantly correlated with one another. A good self-perceived financial situation is associated with high parental educational attainment for both men and women, whereas for women a beneficial perception of the financial situation is also positively correlated with their own level of education.

The modification indices indicated that the four Confirmatory Factor Analysis (CFA) measurement models (social support, self-esteem, feelings of deprivation and mental health) needed adjustment in terms of allowing error covariances (Table 3), in order to obtain an acceptable model fit. Finally, based on theoretical considerations described in the literature section we estimated a structural equation model with an acceptable model fit (see Table 3 and Figure 1).

The results of our structural equation model (see Table 4, Figures 2 and 3) show that cultural capital (the educational level of the respondent; educational level of one's parents) relates to mental health outcomes among men and women in a different way. More specifically, the relationship between a women's educational level and mental health is fully mediated through feelings of deprivation and self-esteem. A higher educational level leads to a lower presence of feelings of deprivation $(\beta=-0.115)$ which in turn relates to higher self-esteem $(\beta=-0.441)$, this is ultimately associated with a good mental health $(\beta=-0.622)$. This mediation is not found among men. For men, a higher educational level of 
the parents is significantly associated with poor mental health $(\beta=0.171)$. For women, the relationship between the educational level of the parents on mental health is fully mediated through self-esteem. A higher educational level of the parents results in lower self-esteem among women $(\beta=-0.133)$, which in turn leads to adverse mental health outcomes $(\beta=0.622)$.

Table 2. Descriptive statistics between dependent and independent variables $(N$, mean, Standard Deviation and Correlations).

\begin{tabular}{|c|c|c|c|c|c|c|c|c|c|c|c|}
\hline & & & & (1) & (2) & (3) & (4) & (5) & (6) & (7) & (8) \\
\hline \multicolumn{12}{|c|}{ Men } \\
\hline & $N$ & Mean & St. Dev. & & & & Corre & tion & & & \\
\hline (1) & 499 & - & - & 1 & & & & & & & \\
\hline (2) & 422 & - & - & $0.165^{*}$ & 1 & & & & & & \\
\hline (3) & 507 & - & - & 0.039 & $0.302 *$ & 1 & & & & & \\
\hline (4) & 513 & 22.67 & 2.452 & -0.060 & 0.263 * & $0.546^{*}$ & 1 & & & & \\
\hline (5) & 488 & 33.00 & 7.576 & 0.028 & 0.169 * & $0.189 *$ & 0.081 & 1 & & & \\
\hline (6) & 484 & 9.13 & 4.278 & $-0.267^{*}$ & $-0.160 *$ & $-0.141 *$ & -0.089 & $-0.341 *$ & 1 & & \\
\hline (7) & 498 & 30.82 & 4.930 & 0.088 & 0.046 & $0.135^{*}$ & 0.053 & $0.417^{*}$ & $-0.421 *$ & 1 & \\
\hline (8) & 501 & 2.66 & 2.856 & -0.046 & $0.114^{*}$ & -0.020 & -0.025 & $-0.251 *$ & $0.281 *$ & $-0.474^{*}$ & 1 \\
\hline \multicolumn{12}{|c|}{ Women } \\
\hline (1) & 597 & - & - & 1 & & & & & & & \\
\hline (2) & 507 & - & - & 0.240 * & 1 & & & & & & \\
\hline (3) & 604 & - & - & 0.150 * & 0.333 * & 1 & & & & & \\
\hline (4) & 613 & 22.88 & 2.340 & 0.048 & $0.258 *$ & 0.568 * & 1 & & & & \\
\hline (5) & 593 & 33.60 & 6.667 & $0.270 *$ & $0.131 *$ & $0.151 *$ & $0.110^{*}$ & 1 & & & \\
\hline (6) & 590 & 7.94 & 3.760 & $-0.183 *$ & $-0.127^{*}$ & $-0.131 *$ & -0.079 & $-0.317^{*}$ & 1 & & \\
\hline (7) & 598 & 29.31 & 4.981 & $0.100 *$ & -0.041 & 0.055 & 0.015 & $0.286^{*}$ & $-0.436^{*}$ & 1 & \\
\hline (8) & 605 & 3.95 & 3.420 & $-0.154^{*}$ & 0.011 & 0.019 & 0.063 & $-0.308^{*}$ & $0.287^{*}$ & $-0.519 *$ & 1 \\
\hline
\end{tabular}

Note a: (1) Self-perceived financial situation (good); (2) Degree parents (high); (3) Degree individual (high); (4) Age; (5) Social support (high); (6) Feelings of deprivation (high); (7) Self-esteem (high); (8) Mental health (poor); Note b: * $p \leq 0.05$.

Table 3. Summary of the goodness-of-fit statistics for the CFA measurement models and structural equation model.

\begin{tabular}{|c|c|c|c|c|c|c|}
\hline & Actions & QMLMV $\varnothing^{2}(\mathrm{df})$ & RMSEA & CI RMSEA 90\% & CFI & TLI \\
\hline \multicolumn{7}{|l|}{ CFA measurement model } \\
\hline \multicolumn{7}{|l|}{ Mental health } \\
\hline$\overline{\text { Mental health }}$ - baseline & & $647.047(130)$ & 0.084 & $0.078-0.091$ & 0.850 & 0.848 \\
\hline Mental health-adapted & Allow 16 error covariances & $186.533(98)$ & 0.040 & $0.031-0.049$ & 0.974 & 0.965 \\
\hline \multicolumn{7}{|l|}{ Feelings of deprivation } \\
\hline$\overline{\text { Feelings of deprivation - baseline }}$ & & $74.588(18)$ & 0.076 & $0.059-0.095$ & 0.975 & 0.972 \\
\hline Feelings of deprivation-adapted & Allow 1 error covariance & $31.325(16)$ & 0.042 & $0.019-0.064$ & 0.993 & 0.992 \\
\hline \multicolumn{7}{|l|}{ Social support } \\
\hline$\overline{\text { Social support_-baseline }}$ & & $424.731(54)$ & 0.111 & $0.102-0.121$ & 0.909 & 0.906 \\
\hline Social support—adapted & Allow 8 error covariances & $44.242(38)$ & 0.017 & $0.000-0.036$ & 0.998 & 0.998 \\
\hline \multicolumn{7}{|l|}{ Self-esteem } \\
\hline 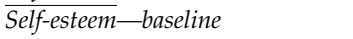 & & $714.987(88)$ & 0.114 & $0.106-0.121$ & 0.768 & 0.763 \\
\hline Self-esteem-adapted & Allow 19 error covariances & $86.251(50)$ & 0.036 & $0.023-0.049$ & 0.987 & 0.976 \\
\hline \multicolumn{7}{|l|}{ Structural equation model } \\
\hline Final model & & $2381.422(1345)$ & 0.037 & $0.034-0.039$ & 0.929 & 0.923 \\
\hline
\end{tabular}

Note: $N=1.151$, QMLMV: Quasi Maximum Likelihood method with Missing Values, RMSEA: Root Mean Squared Error of Approximation, CI: Confidence intervals, CFI: Comparative Fit Index, TLI: Tucker-Lewis Index.

Regarding the second form of capital, economic capital, the relationship between one's financial situation and mental health among women is a direct one. A better financial situation is related to a good mental health $(\beta=-0.158)$. For men, this relationship is fully mediated through feelings of deprivation and self-esteem. A good financial situation is significantly associated with the presence of feelings of deprivation $(\beta=-0.151)$ through which it positively relates to self-esteem $(\beta=-0.351)$, ultimately leading to a better mental health $(\beta=-0.546)$. 
With regards to social capital, the relationship with mental health among men and women is mediated through feelings of deprivation and self-esteem. Two mediating pathways are found. Firstly, high social support relates to higher self-esteem (men $\beta=0.342$-women $\beta=0.214$ ), which in turn results in a better mental health (men $\beta=-0.546-$ women $\beta=-0.622$ ). Secondly, high social support results in lower presence of feelings of deprivation (men $\beta=-0.404-$ women $\beta=-0.290$ ), fewer feelings of deprivation have a positive relationship with self-esteem (men $\beta=-0.351-$ women $\beta=-0.441$ ), which is ultimately related to better mental health outcomes (men $\beta=-0.546$-women $\beta=-0.622$ ). For men, this is a full mediation; for women, however, this is only a partial mediation because of a direct relationship between social support and better mental health $(\beta=-0.120)$. We also calculated the models for men and women without specifying the mediation between feelings of deprivation and self-esteem. Here, the direct relation between feelings of deprivation and mental health remained insignificant.

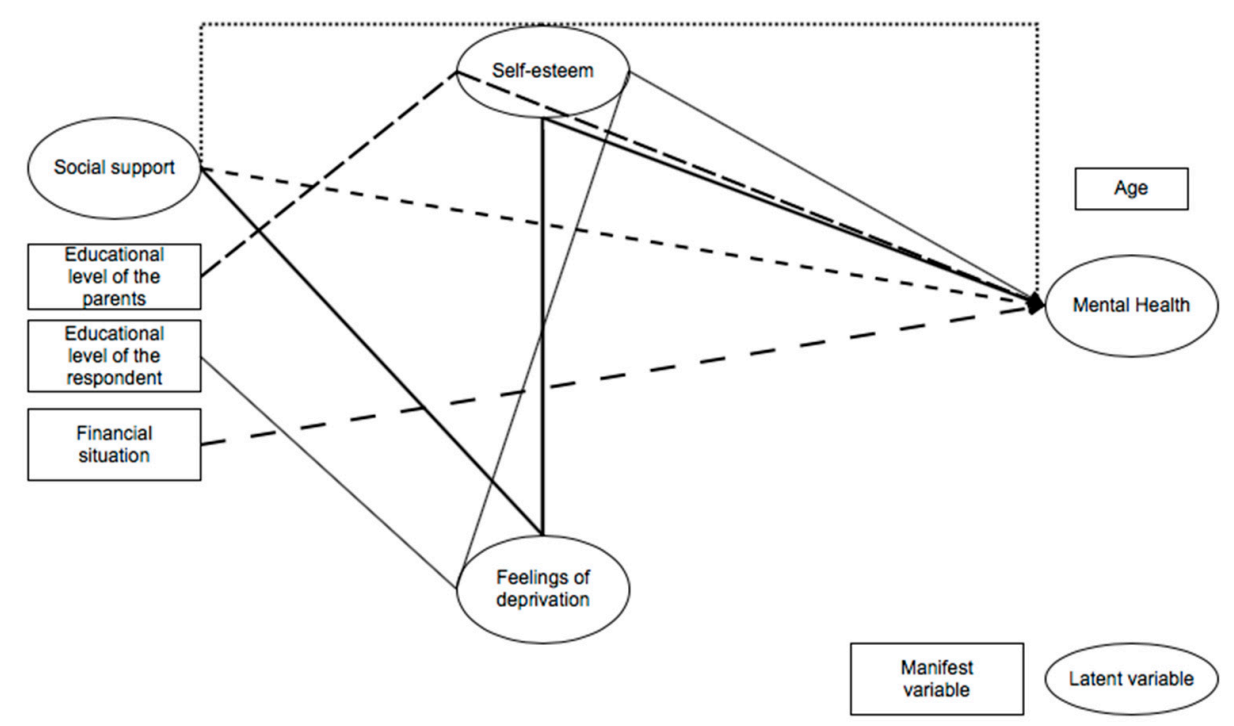

Figure 2. Visual representation of the different paths of the structural equation analysis-women. Note: Each path is represented with a different line. Estimates of the paths can be consulted in Table 4.

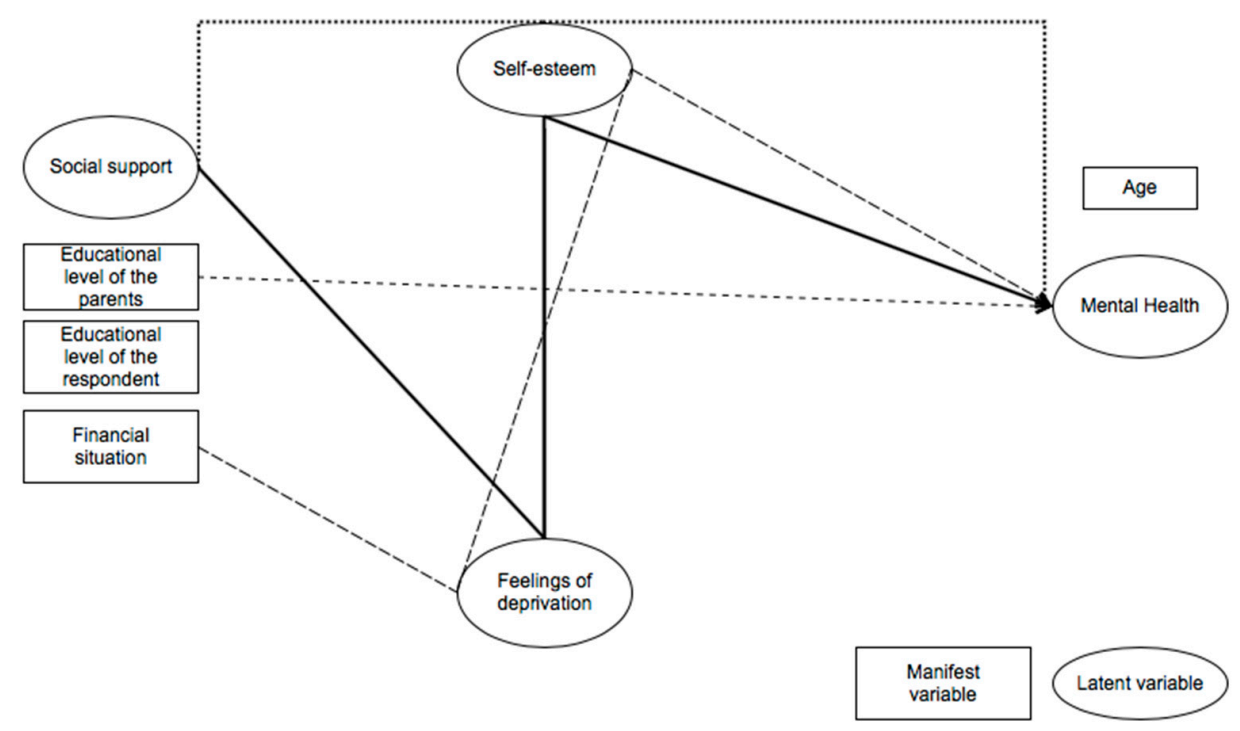

Figure 3. Visual representation of the different paths of the structural equation analysis-men. Note: Each path is represented with a different line. Estimates of the paths can be consulted in Table 4 . 
Table 4. Standardised results of a multi-group structural equation model on the mental health of unemployed Brussels youth in 2015 stratified by gender.

\begin{tabular}{|c|c|c|c|c|c|c|}
\hline $\begin{array}{l}\text { Structural Equation Model } \\
\text { Men }\end{array}$ & \multicolumn{2}{|c|}{ Direct Effect } & \multicolumn{2}{|c|}{ Indirect Effect } & \multicolumn{2}{|c|}{ Total Effect } \\
\hline \multicolumn{7}{|l|}{ Feelings of deprivation (increasing feelings of deprivation) } \\
\hline Economic capital (improving financial situation) & -0.151 & $* * *$ & & & -0.151 & *** \\
\hline Social capital (increasing social support) & -0.404 & $* * *$ & & & -0.404 & $* * *$ \\
\hline \multicolumn{7}{|l|}{ Cultural capital } \\
\hline Educational level of the parents (increasing educational level) & -0.027 & & & & 0.027 & \\
\hline Respondent's educational level (increasing educational level) & -0.014 & & & & -0.014 & \\
\hline \multicolumn{7}{|l|}{ Self-Esteem (increasing self-esteem) } \\
\hline Feelings of deprivation (increasing feelings of deprivation) & -0.351 & $* * *$ & & & -0.351 & $* * *$ \\
\hline Economic capital (improving financial situation) & 0.027 & & 0.053 & $* *$ & 0.080 & * \\
\hline Social capital (increasing social support) & 0.342 & $* * *$ & 0.142 & $* * *$ & 0.484 & $* * *$ \\
\hline \multicolumn{7}{|l|}{ Cultural capital } \\
\hline Educational level of the parents (increasing educational level) & -0.083 & & -0.009 & & -0.093 & \\
\hline Respondent's educational level (increasing educational level) & 0.063 & & 0.005 & & 0.069 & \\
\hline \multicolumn{7}{|l|}{ Poor mental health } \\
\hline Self-Esteem (increasing self-esteem) & -0.546 & $* * *$ & & & -0.546 & $* * *$ \\
\hline Feelings of deprivation (increasing feelings of deprivation) & 0.041 & & 0.192 & $* * *$ & 0.234 & *** \\
\hline Economic capital (improving financial situation) & -0.081 & & -0.050 & * & -0.131 & $* *$ \\
\hline Social capital (increasing social support) & -0.039 & & -0.281 & $* * *$ & -0.321 & $* * *$ \\
\hline \multicolumn{7}{|l|}{ Cultural capital } \\
\hline Educational level of the parents (increasing educational level) & 0.171 & $* *$ & 0.052 & & 0.223 & $* * *$ \\
\hline Respondent's educational level (increasing educational level) & -0.006 & & -0.038 & & -0.045 & \\
\hline Age (control variable) & 0.015 & & & & 0.015 & \\
\hline \multicolumn{7}{|l|}{ Women } \\
\hline \multicolumn{7}{|l|}{ Feelings of deprivation (increasing feelings of deprivation) } \\
\hline Economic capital (improving financial situation) & -0.222 & $* * *$ & & & -0.222 & $* * *$ \\
\hline Social capital (increasing social support) & -0.290 & $* * *$ & & & -0.290 & $* * *$ \\
\hline \multicolumn{7}{|l|}{ Cultural capital } \\
\hline Educational level of the parents (increasing educational level) & -0.047 & & & & -0.047 & \\
\hline Respondent's educational level (increasing educational level) & -0.115 & $*$ & & & -0.115 & * \\
\hline \multicolumn{7}{|l|}{ Self-Esteem (increasing self-esteem) } \\
\hline Feelings of deprivation (increasing feelings of deprivation) & -0.441 & $* * *$ & & & -0.441 & $* * *$ \\
\hline Economic capital (improving financial situation) & -0.121 & $* *$ & 0.098 & $* * *$ & -0.023 & \\
\hline Social capital (increasing social support) & 0.214 & $* * *$ & 0.128 & $* * *$ & 0.342 & $* * *$ \\
\hline \multicolumn{7}{|l|}{ Cultural capital } \\
\hline Educational level of the parents (increasing educational level) & -0.133 & $* *$ & 0.020 & & -0.112 & * \\
\hline Respondent's educational level (increasing educational level) & -0.073 & & 0.050 & * & -0.022 & \\
\hline \multicolumn{7}{|l|}{ Poor mental health } \\
\hline Self-Esteem (increasing self-esteem) & -0.622 & $* * *$ & & & -0.622 & $* * *$ \\
\hline Feelings of deprivation (increasing feelings of deprivation) & -0.018 & & 0.274 & $* * *$ & 0.256 & $* * *$ \\
\hline Economic capital (improving financial situation) & -0.158 & $* * *$ & 0.018 & & -0.140 & $* *$ \\
\hline Social capital (increasing social support) & -0.120 & * & -0.208 & $* * *$ & -0.328 & $* * *$ \\
\hline \multicolumn{7}{|l|}{ Cultural capital } \\
\hline Educational level of the parents (increasing educational level) & 0.015 & & 0.071 & * & 0.086 & \\
\hline Respondent's educational level (increasing educational level) & 0.055 & & 0.016 & & 0.071 & \\
\hline Age (control variable) & 0.060 & & & & 0.060 & \\
\hline
\end{tabular}

Note: ${ }^{* * *} p \leq 0.000 ;{ }^{* *} p \leq 0.01 ; * p \leq 0.05$.

\section{Discussion}

Adding to the body of knowledge on the relationship between forms of capital and mental health, we investigated how different mechanisms of embodying forms of capital affect the mental health of unemployed Brussels youth. In doing so, our analysis can help explain how inequalities in mental health come to exist. Our results show that different forms of capital are related to the mental health of unemployed youth. More specifically, the relationship between social capital and mental health is mediated through feelings of deprivation and self-esteem. This in part supports the second hypothesis on uncertainty-reduction, i.e., that self-esteem is an important buffer in the relationship between feelings of deprivation and adverse mental health outcomes. Moreover, our results indicate that the 
presence of feelings of deprivation lowers one's self-esteem. Furthermore, we also found a direct association between social capital and mental health among women. This underlines the direct and indirect importance of social capital during the transition from education to employment-as was shown earlier [7]. Also, these results underline the importance of support from family and friends during this transition $[12,24,25]$. A possible interpretation of these results could be that social support within a group of significant others can be a way to find confirmation that the status of unemployed is a shared misfortune. It may also help to gain knowledge on how to deal with this situation, for example regarding the job search. In this way, social capital can be an important means to reduce uncertainty and to safeguard one's mental health status. The type of social capital that was investigated here could be considered "bonding social capital" (close ties among a socially homogenous population) [55]. However, it should be noted that bridging social capital (ties with members from other social groups) is also found to have a protective association with (mental) health [56].

Economic capital is only directly related to mental health among women, where a good financial situation results in good mental health. We found that - for men-the absence of feelings of deprivation as a result of a good financial situation improves their self-esteem, ultimately leading to better mental health. Our results considering economic capital show a clear gender pattern. In that regard, two major findings are remarkable and provide a starting point for further research: woman's mental health is more directly determined by their financial situation when compared to men and feelings of deprivation play a key role in "the process of embodiment of economic capital" among men. One of the key characteristics of feelings of deprivation is that they articulate a sense of lack of control. So, what may explain the gender differences in the existence of a link between financial situation, feelings of deprivation, self-esteem and mental health for respondents who predominantly still lived with their parents? As a post hoc interpretation related to the notion of the male breadwinner, it could be that men project the financial situation in which they grow up more to their own future financial situation. In this sense, growing up in a financially secure family can reassure men that "they" as well will be able to provide for their family later on. Although our data do not allow us to test this post hoc interpretation empirically, they clearly indicate an interesting gender difference that merits further attention in future empirical research.

With regard to the third form of capital—cultural capital—both the individual and the parental educational level were included. Findings suggest that the educational level of men's parents is negatively related to mental health. For women, the relationship between the parent's educational level and mental health is only explained through self-esteem. In line with our uncertainty-reduction hypothesis, we found that among women a higher own educational attainment is related to better mental health through feelings of deprivation and self-esteem. However, higher feelings of deprivation do not increase self-esteem. Our results are in line with the notion that feelings of deprivation is important during adolescence and it underlines the importance of continued research on feelings of deprivation during different phases in life as was done by several authors [33,34,57-59]. A post hoc interpretation of these results could be that parents' high cultural capital puts additional pressure on the job search process of unemployed men and women. High educational level of the parents can create expectations among both parents and child about how the transition from education to employment should go. When these expectations are not met, this situation can become a source of stress. Since we are unable to test this post hoc interpretation with our data at hand, we believe this can be of interest for future research.

In sum, important mechanisms amounting to mental health vulnerability of unemployed youth during the transition from education to employment were described. We found evidence that different forms of capital are related to mental health. Furthermore, we found evidence that feelings of deprivation are of continued importance during the transition from education to employment. Though, we did not find evidence to support the first hypothesis that feelings of deprivation are directly related to mental health. We did find support for our second hypothesis that forms of capital affect one's mental health through feelings of deprivation and self-esteem. As a consequence, we found 
that different processes of embodiment affect the relationship between forms of capital and mental health for men and women. However, some important questions remain unanswered in this paper. For example: which other mechanisms play an important role in explaining the relationship between unemployment and mental health? For example, how do personality traits such as extraversion, openness to experience, agreeableness, conscientiousness and neuroticism known as the "big five" [60] affect this relationship? And how do they differ among men and women? Moreover, can we expect that the youth who experience negative mental health, will experience more difficulties in finding a job. And if so, can the mechanisms found in this study be of continued importance in explaining inequality in mental health later on in life? More longitudinal data-quantitative and qualitative-are crucial to answer such pressing questions.

Although this study adds interesting new insights to the body of knowledge on the relationship between unemployment and mental health, some limitations need mentioning. A first limitation relates to the data. The variables used as indicators for forms of capital are proxy variables. A second limitation is related to an important on-going debate in the literature. This debate is often referred to as the "selection versus causation"-debate. Some studies suggest that unemployment causes adverse mental health (causation) [61,62], but there is also literature pointing towards the inverse causal order of the relationship (health selection) [19,63] or towards the idea that both causalities interact [64-66]. Although the structural model estimated in this paper suggests a certain causal order in the relationship between the variables included, this causal order is solely based on theoretical assumptions and cannot be formally tested in our data because of their cross-sectional nature. It is thus important to keep in mind that we are unable to make conclusive statements about the direction of relationships or about the start of mental health problems. Research including more life-course data can shed more light on how these different forms of capital ultimately influence one another.

Aside from these limitations, we believe that our study makes an innovative contribution to the existing body of knowledge regarding forms of capital and mental health during the transition from education to employment. Using SEM we revealed explanatory pathways for the relationship between forms of capital and mental health among the unemployed-i.e., the role played by feelings of deprivation and self-esteem. These new insights are not only important in understanding how inequalities in mental health among unemployed youth emerge. They highlight the importance of the trajectory prior to unemployment. Furthermore, our results underline the importance of a comfortable financial situation and the relationship with mental health. As such, our results can contribute to ongoing policy debates regarding the importance of attributing unemployment benefits to youth during this transition and the more restrictive measures that were recently taken regarding the eligibility criteria for unemployment benefits. However, in spite of these strengths and contributions in explaining the complexities inherent to youth unemployment, more research on youth unemployment and mental health is highly recommended.

Author Contributions: K.H. is the corresponding author of the manuscript and was involved in the acquisition of the 2015 data under the supervision of C.V. K.H. performed the statistical analysis and drafted the manuscript, which was read and revised by C.V. and B.S. All authors read and approved the final manuscript.

Funding: The research for this article was supported by the Public Employment Service Actiris and the Brussels-Capital Health and Social Observatory. These organizations provided respectively non-financial practical support and scientific advice. Financial support was granted by Innoviris (PRFB 2014-14) and the Flemish Community Commission (AD2/WGG/GZ/DF/14-256).

Acknowledgments: The authors would like to thank the Public Employment Service Actiris and L.M. for their contributions in collecting the BCR-data and K.V.A. for the language editing of this manuscript.

Conflicts of Interest: The authors declare no conflict of interest. 


\section{References}

1. Salmela-Aro, K. Academic expectations and well-being from school to work during the economic downturn. New Dir. Youth Dev. 2012, 135, 57-64. [CrossRef] [PubMed]

2. Wheaton, B. Life Transitions, Role Histories, and Mental Health. Am. Sociol. Rev. 2013, 55, $209-223$. [CrossRef]

3. International Labour Office. World Employment and Social Outlook: Trends 2015; International Labour Office: Geneva, Switzerland, 2015.

4. European Trade Union Institute (ETUI). Unemployment, Internal Devaluation and Labour Market Deregulation in Europe; Myant, M., Theodoropoulou, S., Piasna, A., Eds.; ETUI: Brussel, Belgium, 2016.

5. Eurofound. Social Inclusion of Young People; Eurofound: Luxembourg, 2015.

6. Brussels Observatorium voor de Werkgelegenheid. Evolutie van de Brusselse Arbeidsmarkt. Maandverslag-Juni 2016; Brussels Observatorium voor de Werkgelegenheid: Brussel, Belgium, 2016.

7. Huegaerts, K.; Puig-Barrachina, V.; Vanroelen, C. The mental health of unemployed Brussels youth: The role of social and material resources. Arch. Public Heal. 2017, 75, 11. [CrossRef] [PubMed]

8. Norström, F.; Janlert, U.; Hammarström, A. Is unemployment in young adulthood related to self-rated health later in life? Results from the Northern Swedish cohort. BMC Public Health 2017, 17, 12. [CrossRef] [PubMed]

9. West, P.; Sweeting, H. Nae job, nae future: young people and health in a context of unemployment. Health Soc. Care Community 2007, 4, 50-62. [CrossRef]

10. Strandh, M.; Hammarström, A.; Nilsson, K.; Nordenmark, M.; Russel, H. Unemployment, gender and mental health: The role of the gender regime. Sociol. Health Illn. 2013, 35, 649-665. [CrossRef] [PubMed]

11. Puig-Barrachina, V.; Malmusi, D.; Marténez, J.M.; Benach, J. Monitoring social determinants of health inequalities: The impact of unemployment among vulnerable groups. Int. J. Health Serv. 2011, 41, 459-482. [CrossRef] [PubMed]

12. Waithaka, E.N. Family capital: Conceptual model to unpack the intergenerational transfer of advantage in transitions to adulthood. J. Res. Adolesc. 2014, 24, 471-484. [CrossRef]

13. Bourdieu, P. The Forms of Capital. In Handbook of Theory and Research for the Sociology of Education; Richardson, J.E., Ed.; Greenword Press: Westfield, CT, USA, 1986; pp. 241-258.

14. Borlagdan, J. Inequality and 21-year-olds' negotiation of uncertain transitions to employment: a Bourdieusian approach. J. Youth Stud. 2015, 18, 839-854. [CrossRef]

15. Bacikova-Sleskova, M.; van Dijk, J.P.; Geckova, A.M.; Nagyova, I.; Salonna, F.; Reijneveld, S.A.; Groothoff, J.W. The impact of unemployment on school leavers' perception of health. Mediating effect of financial situation and social contacts? Int. J. Public Health 2007, 52, 180-187. [CrossRef] [PubMed]

16. Crowe, L.; Butterworth, P.; Leach, L. Financial hardship, mastery and social support: Explaining poor mental health amongst the inadequately employed using data from the HILDA survey. SSM Popul. Heal. 2016, 2, 407-415. [CrossRef] [PubMed]

17. Najman, J.M.; Hayatbakhsh, M.R.; Clavarino, A.; Bor, W.; O'Callaghan, M.J.; Williams, G.M. Family poverty over the early life course and recurrent adolescent and young adult anxiety and depression: A longitudinal study. Am. J. Public Health 2010, 100, 1719-1723. [CrossRef] [PubMed]

18. Landstedt, E.; Coffey, J.; Nygren, M. Mental health in young Australians: A longitudinal study. J. Youth Stud. 2016, 19, 74-86. [CrossRef]

19. Schaufeli, W.B. Youth unemployment and mental health: Some Dutch findings. J. Adolesc. 1997, $20,281-292$. [CrossRef] [PubMed]

20. McKenzie, S.K.; Carter, K.N.; Blakely, T.; Ivory, V. Effects of childhood socioeconomic position on subjective health and health behaviours in adulthood: How much is mediated by adult socioeconomic position? BMC Public Health 2011, 11, 10. [CrossRef] [PubMed]

21. Cooper, D.; McCausland, W.D.; Theodossiou, I. The health hazards of unemployment and poor education: The socioeconomic determinants of health duration in the European Union. Econ. Hum. Biol. 2006, 4, $273-297$. [CrossRef] [PubMed]

22. Cooper, D.; McCausland, W.D.; Theodossiou, I. Unemployed, uneducated and sick: the effects of socio-economic status on health duration in the European Union. J. R. Stat. Soc. Ser. A 2008, 171, 939-952. [CrossRef] 
23. Pinto-Meza, A.; Moneta, M.V.; Alonso, J.; Angermeyer, M.C.; Bruffaerts, R.; Caldas De Almeida, J.M.; De Girolamo, G.; De Graaf, R.; Florescu, S.; Kovess Masfety, V.; et al. Social inequalities in mental health: Results from the EU contribution to the World Mental Health Surveys Initiative. Soc. Psychiatry Psychiatr. Epidemiol. 2013, 48, 173-181. [CrossRef] [PubMed]

24. Kawachi, I.; Kennedy, B.P.; Glass, R. Social capital and self-rated health: A contextual analysis. Am. J. Public Health 1999, 89, 1187-1193. [CrossRef] [PubMed]

25. Axelsson, L.; Ejlertsson, G. Self-reported health, self-esteem and social support among young unemployed people: A population-based study. Int. J. Soc. Welf. 2002, 11, 111-119. [CrossRef]

26. Krieger, N. Epidemiology and the Web of Causation: Has Anyone Seen the Spider? Soc. Sci. Med. 1994, 39, 887-903. [CrossRef]

27. Krieger, N. Theories for social epidemiology in the 21st century: An ecosocial perspective. Int. J. Epidemiol. 2001, 30, 668-677. [CrossRef] [PubMed]

28. Krieger, N. Proximal, distal, and the politics of causation: What's level got to do with it? Am. J. Public Health 2008, 98, 221-230. [CrossRef] [PubMed]

29. France, A. Understanding youth in the global economic crisis.; Policy Press University of Bristol: Bristol, UK, 2016.

30. Atkinson, W.; Roberts, S.; Savage, M. (Eds.) Class Inequality in Austerity Britain Power, Difference and Suffering; Palgrave Macmillan: London, UK, 2013.

31. Derks, A. Individualisme Zonder Verhaal. Een Onderzoek naar de Verspreiding en de Betekenis van Individualisme Vertogen in Vlaanderen; VUBPRESS: Brussel, Belgium, 2000.

32. Abel, T.; Fuhr, D.C.; Bisegger, C.; Ackermann Rau, S. Money is not enough: exploring the impact of social and cultural resources on youth health. Scand. J. Public Health 2011, 39, 57-61. [CrossRef] [PubMed]

33. Pelleriaux, K. Demotie en Burgerschap; VUBPRESS: Brussel, Belgium, 2001.

34. Van Houtte, M.; Stevens, P.A.J. The culture of futility and its impact on study culture in technical/vocational schools in Belgium. Oxf. Rev. Educ. 2010, 36, 23-43. [CrossRef]

35. Van Houtte, M.; Stevens, P.A.J. Tracking and sense of futility: The impact of between-school tracking versus within-school tracking in secondary education in Flanders (Belgium). Br. Educ. Res. J. 2015, 41, 782-800. [CrossRef]

36. Corrigan, P.W.; Bink, A.B.; Schmidt, A.; Jones, N.; Rüsch, N. What is the impact of self-stigma? Loss of self-respect and the "why try" effect. J. Ment. Heal. 2015, 25, 10-15. [CrossRef] [PubMed]

37. Hogg, M.A. Uncertainty, Social Identity, and Ideology. Soc. Identif. Groups 2015, 22, 203-229. [CrossRef]

38. Hogg, M.A. Subjective Uncertainty Reduction through Self-categorization: A Motivational Theory of Social Identity Processes. Eur. Rev. Soc. Psychol. 2000, 11, 223-255. [CrossRef]

39. Waters, L.E.; Moore, K.A. Predicting self-esteem during unemployment: the effect of gender, financial deprivation, alternate roles, and social support. J. Employ. Couns. 2002, 39, 171-189. [CrossRef]

40. Huurre, T.; Aro, H.; Rahkonen, O. Well-being and health behaviour by parental socioeconomic status. A follow-up study of adolescents aged 16 until age 32 years. Soc. Psychiatry Psychiatr. Epidemiol. 2003, 38, 249-255. [CrossRef] [PubMed]

41. Ümmet, D. Self Esteem among College Students: A Study of Satisfaction of Basic Psychological Needs and Some Variables. Procedia Soc. Behav. Sci. 2015, 174, 1623-1629. [CrossRef]

42. Waddell, G. Labor-market consequences of poor attitude and Low self-esteem in youth. Econ. Inq. 2006, 44, 69-97. [CrossRef]

43. Zimmer, H. Mismatches op de arbeidsmarkt. Econ. Tijdschr. 2012, September, 59-74.

44. FOD Economie-ADSEI Arbeidsmarktindicatoren Volgens Leeftijd en Geslacht-Absolute en Relatieve Cijfers (1999, 2de Kwartaal 2016). Available online: http://statbel.fgov.be/nl/modules/publications/ statistiques/arbeid (accessed on 2 September 2016).

45. Brussels Observatorium voor de Werkgelegenheid. De Arbeidsmarkt in het Brussels Hoofdstedelijk Gewest Situatie 2012; Brussels Observatorium voor de Werkgelegenheid: Brussel, Belgium, 2012.

46. Goldberg, D.; Williams, P. A User's Guide to the General Health Questionnaire; NFER-Nelson: Windsor, UK, 1988.

47. Zulkefly, S.N.; Baharudin, R. Using the 12-item General Health Questionnaire (GHQ-12) to Assess the Psychological Health of Malaysian College Students. Glob. J. Health Sci. 2010, 2, 73-80. [CrossRef]

48. Broadhead, W.E.; Gehlbach, S.H.; DeGruy, F.V.; Kaplan, B.H. The Duke-UNC Functional Social Support Questionnaire: Measurement of Social Support in Family Medicine Patients. Med. Care 1988, 26, 709-723. [CrossRef] [PubMed] 
49. Rosenberg, M. Society and the Adolescent Self-Image; Princeton Univerity Press: Princeton, NJ, USA, 1965.

50. Steiger, J.H. Understanding the limitations of global fit assessment in structural equation modeling. Pers. Individ. Dif. 2007, 42, 893-898. [CrossRef]

51. Hu, L.; Bentler, P.M. Cutoff criteria for fit indexes in covariance structure analysis: Conventional criteria versus new alternatives. Struct. Equ. Model. A Multidiscip. J. 1999, 6, 1-55. [CrossRef]

52. Brown, T.A. Confirmatory factor analysis of the Penn State Worry Questionnaire: Multiple factors or method effects? Behav. Res. Ther. 2003, 41, 1411-1426. [CrossRef]

53. Brown, T.A. Confirmatory Factor Analysis for Applied Research; Kenny, D.A., Ed.; The Guilford Press: New York, NY, USA, 2006.

54. Kenny, D.A. Mediation. Available online: http://davidakenny.net $/ \mathrm{cm} / \mathrm{mediate}$.htm (accessed on 30 November 2016).

55. Putnam, R.D. Bowling Alone; ACM Press: New York, NY, USA, 2000; p. 357.

56. Kim, D.; Subramanian, S.V.; Kawachi, I. Bonding versus bridging social capital and their associations with self rated health: A multilevel analysis of 40 US communities. J. Epidemiol. Community Health 2006, 60, 116-122. [CrossRef] [PubMed]

57. Spruyt, B.; Van Droogenbroeck, F.; Kavadias, D. Educational tracking and sense of futility: A matter of stigma consciousness? Oxf. Rev. Educ. 2015, 41, 747-765. [CrossRef]

58. Van Houtte, M.; Stevens, P.A.J. Sense of Futility: The Missing Link Between Track Position and Self-Reported School Misconduct. Youth Soc. 2008, 40, 245-264. [CrossRef]

59. Van Houtte, M. Global Self-Esteem in Technical/Vocational Versus General Secondary School Tracks: A Matter of Gender? Sex Roles 2005, 53, 753-761. [CrossRef]

60. Goldberg, L.R. The Development of Markers for the Big-Five Factor Structure. Psychol. Assess. 1992, 4, $26-42$. [CrossRef]

61. Jin, R.; Shah, C.P.; Svoboda, T.J. The impact of unemployment on health: A review of the evidence. Can. Med. Assoc. J. 1995, 153, 529-540. [CrossRef]

62. Fryer, D. International perspectives on youth unemployment and mental health: Some central issues. J. Adolesc. 1997, 20, 333-342. [CrossRef] [PubMed]

63. Hammarström, A. Health consequences of youth unemployment. Public Health 1994, 108, 403-412. [CrossRef]

64. Paul, K.I.; Moser, K. Unemployment impairs mental health: Meta-analyses. J. Vocat. Behav. 2009, 74, $264-282$. [CrossRef]

65. Herbig, B.; Dragano, N.; Angerer, P. Health in the long-term unemployed. Dtsch. Arztebl. Int. 2013, 110, 413-419. [CrossRef] [PubMed]

66. McKee-Ryan, F.; Song, Z.; Wanberg, C.R.; Kinicki, A.J. Psychological and physical well-being during unemployment: A meta-analytic study. J. Appl. Psychol. 2005, 90, 53-76. [CrossRef] [PubMed] 